\title{
Speculative development and the origins and history of East India Company settlement in Cavendish Square and Harley Street
}

As London grew north and west in the eighteenth century, wealth settled on the new-built streets of the Cavendish-Harley (later Portland, now Howard de Walden) estate. This paper describes how, why and where individuals enriched through the East India Company came to ground in this part of London. The cases of Francis Shepheard, scion of an important company family, Governor Robert Adams, in flight from Tellicherry, his nephew Robert Orme, the historian of India, General Richard Smith, a notorious 'Nabob', and a few others elucidate the market-based origins and accidental then deliberate consolidation of this settlement and stand for many more East India Company names about whom at this point less is known.

\section{KEYWORDS}

speculative housing, East India Company, Cavendish Square, Harley Street, nabob,

The transfer to London of wealth derived from commerce in India based in the activities of the East India Company was great and ramifying. But its points of landing and consequences are difficult to pin down. Many individual stories have been told and the impact of investment on British country houses in particular has been widely investigated, with a major project focusing on where and how wealth from India was spent in Britain recently completed. ${ }^{1}$ It is well known that as London's West End grew northwards into the parish of St Marylebone in the eighteenth century the area was in significant measure populated by those with repatriated wealth from the Caribbean and India, and West Indian connections have now been mapped and quantified. ${ }^{2}$ That Harley Street and its immediate area in the West End had come by the early nineteenth century to be particularly associated with 'nabobs' returned well-heeled from India is also readily discovered. But there has been little close study of this London settlement and its origins have been obscure. This paper delves into the subject, aiming to open it up through individual case studies. It argues for an essentially economic explanation of origins, downplaying socio-cultural emphasis at the outset. It is an illustrative account and makes no claim to be comprehensive or definitively explicative. ${ }^{3}$

What follows is largely about speculative housing, buildings erected for habitation by the wealthy in market conditions that made it hard to control exactly who those wealthy people would be. The West End house of the eighteenth century is a much celebrated almost quintessential type. It has been a prominent marker, a kind of cultural trope, through successive twentieth-century interpretations. Despite the clear explanations of eighteenth-century West End 
development set out in John Summerson's enduringly valuable Georgian London (1945), followed by much other architectural history, recent scholarship of a socio-cultural and identity focussed nature has sometimes overlooked the fact that virtually all the West End's houses went up as speculations and that supply generally exceeded demand. This has tended to favour teleological understandings of both architecture and settlement that give too much agency to owners and occupiers, too little to the market or the 'invisible hand', what in an evolutionary context would be called 'natural selection'. The result has been an approach to material culture that elides a crucial aspect of how the period's materiality was experienced. ${ }^{4}$

The building of high-status speculative houses is a risky business, vulnerable to the turbulence of credit markets and building cycles; fastidiousness as to the source of investment is generally unwise. For this reason the buildings discussed here do not in themselves reflect anything much by way of an East India Company identity. That is by and large not what is being interrogated. The divinity that shapes the ends being traced here is a complex mix of aspiration and design on the parts of both builders and occupants, chance and, above all, market forces. The result was the filling from India of an opening at the top end of London's residential market. Or, to put it another way, new money from India was what the market supplied to help fill Marylebone's otherwise surplus smart houses. As is often the case, once the link was established it was reinforced through family relationships, professional and other networks and less tangible collective interdependence. Those returning from South Asia having made their fortune there became a particularly close-knit group, especially in the second half of the eighteenth century when they became the objects of public prejudice, branded as 'nabobs' and viewed with distrust. Studies of other wealthy social groups, such as Americans and West Indian planters, groups which also favoured Marylebone for their London residences, have shown similar settlement patterns at this time. ${ }^{5}$ One thing leads to another, people cohere and colonial economies pervaded the West End.

Taking the period of the development of the CavendishHarley/Portland Estate from its beginnings in the early eighteenth century through ups and downs and its heyday from the 1750s on to the mid-nineteenth century when its earlier prestige was beginning to fade, there is a direct correlation with the fortunes of the East India Company itself. In the early eighteenth century the Company enjoyed great prominence, strength and profitability. But it was in the second half of the century that opportunities for individual fortunes reached their peak, leading to the emergence of the returning nabob. Whilst some such as Robert Clive were of old landed families sent out to restore depleted coffers, many more were of humbler stock and perceived to be upstarts. On their return to Britain they possessed sufficient new wealth to aspire to the life of a gentleman: a country estate, a town house and a seat in parliament. For most returning from Indian service, their desire was for 'ease and relaxation' rather 
than continued investment in trade or manufacture. ${ }^{6}$

The rapid pace of development on the Portland estate in the second half of the eighteenth century was given added impetus by the laying out of the New Road in 1756-7. This major thoroughfare transformed the accessibility of Marylebone from the City, which mattered to those with East India Company connections. But it also set a highly visual northern boundary to the urban core. Situated at the edge of this rapidly growing city, Marylebone was perceived as neither of the town nor out of it. It offered respite from the hubbub of the inner areas, open space on its doorstep and clear air. ${ }^{7}$ Marylebone therefore almost immediately reinforced its attractions as a desirable and fashionable location, but fashion moved fast and the southern and eastern parts of the parish where building development began earlier, were soon eclipsed as the most desirable neighbourhoods and the newer houses in the upper stretches of Wimpole and Harley Streets and Portland Place gained the ascendance.

As the century wore on the East India Company's dominance began to wane, with growing pressure to end its monopoly on trade. Beginning with the Regulatory Act of 1773, government intervention in Company business started to grow. Though the Company's commercial interests declined its importance to the government of India remained key. Marylebone residents of this later phase were more generally Company directors or stock holders, and included the director David Scott, who was a central figure in reform of the Company. ${ }^{8}$

\section{Cavendish Square}

Cavendish Square was the centrepiece of London's first significant expansion north of Oxford Street, speculative development on the Cavendish-Harley estate that began in 1717. Robert Harley's son Edward, later the 2nd Earl of Oxford and Earl Mortimer, inherited the land in 1713 through marriage to Lady Henrietta Cavendish Holles. At first, Tory grandees who were political associates of the elder Harley were lined up to build, to give the project prestige and attract others. The 1st Viscount Harcourt, Baron Bingley and the Duke of Chandos took sites on three sides of the square and began building great houses. Progress was slow, set back by the bursting of the South Sea Bubble in 1720, and less palatial than first intended. The square's frontages were gradually but not more than partially filled. The investors who followed on through the 1720 s were less august and less Tory. More northerly plots remained open, something of a notorious embarrassment, and were only gradually filled up to 1770 (see below).

Several of the houses of the 1720 s still stand. Nos $3-5$ on the east side, begun in 1720, but passed from one bankrupt builder to others and only complete in 1727 , were first occupied by two Whig MPs (John Neale and Walter Plumer) and James Naish, a financier and a director of both the London Assurance Corporation and the Royal African Company. Nos 4 and 5 had been finished by Thomas Milner, a 
former salt commissioner and a member of the York Buildings Company's committee, so very probably an associate of Chandos's, and George Greaves, a Clerkenwell carpenter. The finest surviving house of the 1720 s at what is now No. 20 on the square's west side was built to fill most of a gap south of Bingley's mansion on the west side. Here, inside a stone carapace of the 1930s in what is now the headquarters of the Royal College of Nursing, is one of London's best surviving early eighteenth-century painted staircases (Figure 1). The house was built and decorated in 1726-30. Milner held the site and was chivvied to get on with its development. Greaves built the house with a mortgage from Naish. The first occupant was Francis Shepheard (1676-1739), the scion of an East India Company family, a wine trader and a former MP who had moved from the Whigs to the Harleyite Tories. ${ }^{9}$ His new political allegiance might provide reason enough for his decision to take a house on the Cavendish-Harley estate, but his connections went deeper. Shepheard's father Samuel had been an MP, Robert Harley's financier and Deputy Governor of the South Sea Company from 1713. Before that he had made his name as a prominent critic of the East India Company in the 1690s. After the anti-monopoly legislation of 1698 he was one of the founders of the new East India Company, and in 1708 one of the first directors of the united Company. ${ }^{10}$ When he died in 1719 he left a fortune to his eldest son, Francis. ${ }^{11}$ Painted staircases like this did not come cheap. The north side of the square was sold entirely to the Duke of Chandos, whose princely wealth had been built up through speculative opportunities offered by his position as paymaster of the armed forces from 1705 to $1713 .{ }^{12} \mathrm{He}$ intended a full-width palace, something without parallel in London. But, in somewhat reduced circumstances after 1720, drew back. After much havering he decided to build two houses, one at either end of the property. These were substantial dwellings, mansions in their own right (Figure 2). Chandos probably intended them for his two sons - he now had a townhouse on St James's Square. ${ }^{13}$ Building work began in 1724, but the houses remained unfinished in 1727 when Chandos's eldest son, John, died aged 24. He decided to keep the western house for himself and to sell the other, eastern one. ${ }^{14}$ It was not until 1730 that a buyer was secured. Chandos was advised not to let him go as another might not come forward. Difficulty selling such a huge house is not surprising. Chandos and his proximity would have put off many from society's upper echelons, and Chandos knew that 'Cavendish Square is not so well liked as to render it easy to meet with tenants for so large a house'. The only money around was distastefully new money. The catch was Governor Robert Adams - in Chandos's words not 'a very steady man'. ${ }^{15}$

But he was a colourful man and, it seems, a unique upstart. Adams had recently arrived in London from India. He had lived there since a child in 1687 and on the north Malabar (Kerala) coast acquired fluency in Malayalam. As a young man he gained charge of the East India Company factory or trading depot at Calicut where he cultivated 
good relations with the Zamorin, the ruler of the kingdom centred there, forming an alliance against the Dutch and Cochin. In 1715 Adams devised and financed a plan for the Zamorin to reconquer Chettuva from the Dutch. It succeeded and Adams built a warehouse there. But the Dutch fought back, taking three of Adams's munchuas (flat-bottomed boats), and forcing the Zamorin into an unfavourable treaty in 1717 . Adams retreated north up the coast to become governor of the factory at Tellicherry (now Thalassery). This had been established from Surat in 1683 to secure trade in pepper as well as what were said to be the finest cardamoms. When Adams arrived in Tellicherry it had, according to his predecessor, suffered years 'under clouds of misfortune'. ${ }^{16}$

There had been running battles with the local Nair population. These continued and there were deaths in 1723. Adams mediated between the Nair and the Dutch, but defending Tellicherry was costing the Company more than the profits it generated. In Calicut Adams had met and been impressed by Dr Alexander Orme, a physician and surgeon, who in 1707 was based further south at Anjengo (Anchuthengu). It was an enduring bond - Adams married Margaret Hill, Orme her sister. Orme became chief of the station at Anjengo, a place chastened by the massacre in 1721 of a predecessor, William Gyfford, and many under his charge. Orme's second son, Robert, was born there in 1728 , and named after his uncle (see below). ${ }^{17}$ The Malabar stations were generally run at a loss for the private benefit of their chiefs and factors. The profits of the pepper trade were appropriated to personal accounts by men who operated like lords of local manors. The East India Company usually turned a blind eye. Supervision was impractical and ruthless profiteering often brought the company advantage. According to Alexander Hamilton's contemporary account, until 1717 Adams imported Bengal opium and sent it inland from Calicut on the Company's empty pepper munchuas as a profitable private trade. 18

Adams had loaned large amounts of company funds to the Zamorin and other Malabar 'princes' to fight the Dutch. Of this, \&6,424 $171 \frac{11}{2}$ could not be recovered in the late 1720s so the Council of Bombay obliged Adams to sign bonds for its recovery in Fort St George (Madras or Chennai). Fearing he would abscond, the Company detained Margaret, but the couple were able to meet at Calicut and from there to flee to England in 1729.19

In London Adams set about clearing his name and his access to money. He made representations to the Company in September 1729 seeking cancellation of the bonds. These gained a favourable hearing from the Committee of Correspondence in June 1730 and a week later the Court of Directors cleared Adams of responsibility and liability as the transactions with the Zamorin and others had been notified to the Council of Bombay. It was felt, anyway, that the money would soon be paid back. ${ }^{20}$

In fact a bill from Bengal to pay $£ 3,000$ to Adams had been cleared by the Company in May. ${ }^{21}$ This and anticipation of vindication probably 
underlay Adams's upmarket house-hunting. Just days before he was cleared Chandos was writing about the arrangement whereby Adams would finish the fitting out and decoration of the still incomplete house on Cavendish Square. The sale had been settled by October 1730 , the price was $£ 3,400$.

Three 'black servants',22 Edward, Antonio and Abigail, who had come with Adams from India, may have been briefly resident in Cavendish Square. A London winter perhaps came as a shock; they were already keen to return home in February 1730 when Adams sought free passage for them through the Company. This was granted, but not until January 1731.23

In 1732 Adams acquired a coat of arms (Figure 3). Long before, near Calicut, he had, he attested, been 'attacked by a Tyger who Seizd Him on the left Arm, the Marks whereof are still to be seen; But through Providence he had the good Fortune to destroy that Furious Beast, by ripping his Belly with a Lance, that his Guts fell out and immediately died.'24 The coat of arms therefore included 'on a cross gules five mollets or, a tiger salient proper and for his crest on a wreath of the colours a Dexter Arm couped at the Elbow habited in Crimson Velvet holding in the Hand a Lance Proper Stuck into the Belly of a like Tyger.'25

Further substantial sums were remitted to Adams from India through the Company and he evidently settled to a well-appointed retirement up to his death in 1738. He was, along with George Frideric Handel, among the callers at the Dover Street home of the Earl of Oxford and Lady Harley after the marriage in 1734 of their daughter, Lady Margaret Cavendish Harley, to William Bentinck, the 2nd Duke of Portland, at the Oxford Chapel (now St Peter Vere Street). ${ }^{26}$ Cavendish Square was certainly a prestigious address, but not unqualifiedly so. In the same year as the aristocratic marriage James Ralph published a stinging critique of the still only partially built-up square, slating it as a failed speculation: 'there we shall see the folly of attempting great things, before we are sure we can accomplish little ones. Here 'tis, the modern plague of building was first stayed, and I think the rude, unfinish'd figure of this project should deter others from a like infatuation. When we see any thing like grandeur or beauty going forward, we are uneasy till 'tis finish'd, but when we see it interrupted, or intirely laid aside, we are not only angry with the disappointment, but the author too: I am morally assur'd that more people are displeas'd at seeing this square lie in its present neglected condition, than are entertain'd with what was meant for elegance or ornament in it.'27

Adams completed the house's interior, finding a place, no doubt, for the tiger skin which he had kept, and added the plain single-storey range on the west side of the house (Figure 2). ${ }^{28}$ His infant nephew, Robert Orme, had been sent from India to be brought up in the house from the age of two until he was sent to Harrow for schooling in 1734 age six. Orme went back to India in 1742 aged 13 (see below). ${ }^{29}$ Widowed, Margaret Adams had by then vacated the big house and 
moved round the corner to a marginally humbler dwelling at what is now 6 Cavendish Square. The Adams's daughter Elizabeth married Bennet Noel and the larger house was thereafter long in the hands of the Noel family, including Earls of Gainsborough and Gerard Noel, an evangelical anti-slavery MP. ${ }^{30}$ It was demolished in the $1890 \mathrm{~s}$, but a stable and coach-house that Chandos built to the rear survives, much altered and extended, as the Medical Society of London's headquarters on Chandos Street. 31

\section{Harley Street}

With the economic downturn following the South-Sea-Bubble's bursting, the planned northward expansion of the Cavendish-Harley estate came almost to a standstill. Only the southernmost stretch of Harley Street had been set out, and the first buildings there were a rag-tag of houses, a cold bath and a pub, the Blue Posts, built near the track that led to Marylebone village - partly on the line of present day Queen Anne Street. ${ }^{32}$ It was not until the 1750s that speculators had the confidence to start building north of Wigmore Street. Thomas Huddle, a brick-maker who had grown wealthy developing on the Berners' estate further east, was the first to take a sizeable piece of ground here, followed by John Corsar, a bricklayer, and a mason, George Mercer, both also local men.

By 1760 terraces of first-rate houses reached Queen Anne Street. Within ten years the west side of Harley Street was built up as far as New Cavendish Street, and a terrace of seven houses had been built on the east side. Into one of these, originally number 11 , moved Robert Orme in 1764 at the age of 35. This remained his home for the next thirty years (Figure 4). His return to within a stone's throw of the house in which he had passed part of his childhood marks a crucial step towards the entrenchment of East India Company settlement in the neighbourhood. 33

Orme's career with the East India Company was not typical, and unlike so many of his cohort, he did not return with a vast fortune. During his early years in India he had studied widely, but also focused on Indian affairs, writing an essay on 'A general idea of the government and people of Indostan' when still in his early twenties. On a visit to England with Robert Clive in 1753 his knowledge of India won him influential friends who secured him a senior post on the Madras council when he returned to India the following year. By September 1758 he had risen further through the ranks to become deputy to the Governor. But it was at this point that his career began to unravel. Orme was an arrogant man, ambitious and impatient. He had been sending his imperious criticisms of his fellow (and senior) council men back to the directors of the Company in London, and once this apparent duplicity was discovered in Madras his career with the Company came to an abrupt halt. Making no effort to explain or clear his name, he fled India in October 1758 making a slow return to London. ${ }^{34}$

At first he stayed with his aunt Margaret in Cavendish Square before 
taking lodgings on the other side of Oxford Street just off Hanover Square, and then Norfolk Street, before moving to the newly completed house in Harley Street. 35 Orme was not quite the first with connections to India to take up residence in this street. He was preceded by William Martin, a retired Royal Navy Captain on half-pay, who had served in India in 1757-8 as commander of the Cumberland at the Battle of Negapatam under Vice-Admiral George Pocock. ${ }^{36}$ Martin lived in Harley Street from 1761 until his death in 1766. His time in India was remembered in his will, where he named his friends Robert Palk, Governor of Madras, and Henry Vansittart, late Governor of Bengal, as his executors. ${ }^{37}$ After his death his household furniture was sold, and amongst the items advertised for sale were many that suggest an Indian provenance: India cabinets, blue mixed damask window curtains, sofas and chairs, and fine chintz patterned beds and chairs. 38

Although it is plausible that Robert Orme at least knew something of Martin, there is no evidence that they were personally acquainted or that the presence of the aged sea captain had anything to do with Orme's decision to move to the same street. More likely reasons were his early associations with Cavendish Square and the proximity of at least two of his close circle of friends at that time: Edmund Burke, who was just around the corner in Queen Anne Street, and Lauchlin MacLeane, who was then in Holles Street. ${ }^{39}$ Harley Street was a respectable address, with a smattering of aristocratic residents, but it was also affordable. With his relatively modest fortune of a little over $£ 5,500$, Orme could not afford a country estate as well as a townhouse, but the rent of $£ 60$ a year was not beyond his means. His immediate neighbours were Lord Waltham, a young Irish peer and MP, and Captain Staats Long Morris, an American-born army officer who had married the Dowager Duchess of Gordon. Morris was briefly in India, in command of the British troops in Bombay in January 1763, but returned to England in December the same year. He and the Dowager Duchess took up residence in Harley Street in 1766.40 Orme's house, together with those adjoining, was demolished following bomb damage in the Second World War. ${ }^{41}$ It was partially captured in a photograph taken in the 1930s (Figure 5). Externally, at least, these houses were exceedingly plain: brick-faced, of three storeys and attics over a basement and with a shallow area. They were entirely typical of mid-eighteenth century speculative houses in the West End, and were not designed to attract wealthy nabobs any more than the landed gentry or any other citizen who had the wherewithal to take a lease of the property. Behind these sober façades, the interiors were by contrast richly decorated. From a stone flagged entrance hall, stone stairs rose up through the building, most with ornate wrought iron balustrades. The principal rooms on the ground and first floors had decorative plaster ceilings and marble chimneypieces. The chief feature of Orme's house would have been his library. This he finally sold in 1796, together with the lease of his house, due to increasing blindness. He retired to the rural quiet of Ealing, leaving 
behind 'the rumble of Harley Street'. ${ }^{42}$

One of Orme's closest friends was drawn to Harley Street. Orme had known General Richard Smith from his early days in Madras and had cared for his son from 1764 while Smith was in India. When the General returned in April 1770 it was to a house a few doors down from his old friend. ${ }^{43}$ For around seventeen years Smith's townhouse was at 22 Harley Street (originally No.5). It had been built by George Mercer in the late 1750s and was first occupied in 1760 by Sir John Shaw, 4th Baronet, who also held the formerly royal Eltham Lodge. ${ }^{44}$ Although it too has been demolished, photographs taken just prior to demolition in the 1960s show a building much the same as Orme's house. Unusually, No. 22 had retained its brick façade, most had the ground-floor front fashionably stuccoed in the nineteenth century, but modest alterations had been made including the cut-down first-floor windows and added balcony (Figure 6). Inside, a photograph of the entrance hall shows what may well have been the original iron stair balustrade with its mahogany handrail, but the tiled floor is Victorian (Figure 7 ). ${ }^{45}$ It was also no doubt richly furnished, probably with many items brought back from India.

Unlike Orme, General Smith had accumulated an enormous fortune. As well as his townhouse, in 1771 he purchased a country estate, Chilton Lodge, in Berkshire, for $£ 36,000$ from John Zephania Holwell, another ex-East India Company servant and, briefly, a Harley Street resident. ${ }^{46}$ Like Orme, Smith was known for his arrogance, but his great wealth allowed him to indulge his fondness for the gaming table, horses and extra-marital affairs. All this, together with his origins in trade (his father was a cheesemonger) frequently made him the butt of satirists. He was widely recognized as the model for Sir Mathew Mite in Samuel Foote's play The Nabob, first produced in 1772, and, under that name, his biography was given, in no tender light, in the Town and Country Magazine in 1776. At that time he had taken as his mistress the equally notorious courtesan, Mrs Elizabeth Armistead. 47 When Smith was appointed High Sheriff of Berkshire he was said to have favoured proposals for a new road that would allow him to 'arrive at his magnificent seat ... without the necessity of passing through the little stinking town of Hungerford'. ${ }^{48} \mathrm{He}$ also served a six-month jail sentence for bribing his way to a parliamentary seat. In 1783 he was vilified in a pamphlet by Joseph Price, ironically entitled $A$ Vindication of General Richard Smith, in response to his role as chair of the House of Commons Select Committee on East India affairs. ${ }^{49}$

By 1784 Smith's finances were severely depleted and he was forced to sell up his country estate and flee abroad to escape his creditors. 50 The Public Advertiser, always quick to attack Smith's taste and social status, announced that the purchaser of General Smith's place in Berkshire (John Macnamara MP) would have a great deal to do before he could make it fit for 'a gentleman' to live in: 'All the gewgaw work, and excessive decoration, must be destroyed, and almost all the best rooms re-formed and modernised'. ${ }^{51}$ There was perhaps more bile here than accuracy, although even The Times noted that this was where 
Foote, the playwright, declared that he had been served 'diamond dumplings' for his supper. ${ }^{52}$ Macnamara did not keep the house for long. It was up for auction again in 1788 along with the contents. It is possible that some of these may have been Smith's, but the descriptions are vague: suites of rich Damask, Muslin and fine Chintz Patterns ... a variety of Inlaid and fine Mahogany Articles'. There was also mention of some pictures by Angelica Kauffman. 53 Two months later there were plans to demolish the house, and the building materials were advertised for sale. Items listed included marble chimney-pieces 'of superior elegance and exquisite sculpture', mahogany folding doors, other doors with ormolu mountings, and a stone portico. ${ }^{54}$ (The house was not demolished at this date, and almost the same list of fixtures and building materials was readvertised in $1791 .{ }^{55}$ )

During the 1770s and into the 1780s the pace of building on the Portland Estate had been rapid, with new houses now reaching as far north as the New Road (now Marylebone Road) with its easy access to the City. When Orme and Smith had first moved here, their houses were still on the very edge of the expanding metropolis. This suburban aspect was especially appealing to both the old elite and its imitators with newer wealth. In 1765 when one of the houses opposite Orme's was advertised to let, amongst its attractions was the 'delightful prospect over the green fields as far as Highgate'. ${ }^{56}$ This was not to last. In 1771 John White entered into the first of a series of building agreements with the Duke of Portland to continue Harley Street northwards. White was working with a consortium of builders and tradesmen that included his business partner, Thomas Collins, who had established himself as highly skilled in plasterwork and who was part of the circle of William Chambers. John Johnson, the carpenter turned architect, was another of that circle who was involved in designing some of the houses here. The first stretch of the extended Harley Street went up between 1772 and 1776, and the second, north of Weymouth Street was completed by 1778. The final section leading up to the New Road was built in two phases, in the 1780s and the 1820s. 57

White's houses were mostly just a little larger than the earlier ones, and boasted particularly fine interiors, but otherwise were built to harmonize with those of the 1750 s and 1760s. There was some variation in the width and depth of each plot, and a few lacked a coach-house and stables in the mews to the rear. Typically each house contained a hall, with a stone staircase, iron balustrade and mahogany handrail, then two rooms to a floor. The basement contained the servants' quarters - a servants' hall, housekeeper's room, and butler's pantry - while the kitchen was generally described as being 'apart from the house', and seems to have been in the basement below the back yard or garden. ${ }^{58}$

Harley Street was one of the best addresses on the Portland Estate, with Cavendish Square and later Portland Place and Mansfield Street being the grandest with the largest houses. Although there was not a 
great difference in the size of the individual houses in Harley Street, they were not entirely uniform. The largest was taken by another former East India Company servant: John Pybus. Latterly No. 81, this was the only house that had four, rather than the usual three windows across its front. It survives, but with considerable alterations, including the addition of stone window surrounds to the front elevation (Figure 8).

Of modest family background, John Pybus had begun his career with the East India Company as a writer in 1742 when he was about 15 years of age. He became a member of the Council of Madras and in 1762 travelled to Sri Lanka as an ambassador to the King of Kandy. This was the first contact between the Company and the island, prompted by the King's request for help to oust the Dutch. Nothing became of the mission, however, and Pybus went back to Fort St George. ${ }^{59}$ He returned to England in 1768 with his family. Before moving to Harley Street he had lived for a few years in Berners Street; he appears as the first ratepayer of No. 64 in 1769. 60 Amongst his neighbours were (Sir) William Chambers at No. 13, Thomas Collins at No. 44 and John Johnson at No. 32, all of whom were involved in the development of Berners Street. It seems highly likely that one or other of these men was instrumental in Pybus's move to Harley Street. Johnson was a party to Pybus's lease of No. 81, and Collins was John White's partner in the wider development of that stretch of Harley Street. William Gowing, carpenter and John Utterton, plasterer, were also active in the development here and had earlier built houses in Berners Street. Pybus was one of the few who leased directly from the Portland estate, mostly the Portland leases went to the developers who then assigned or sub-let to tenants. This might suggest that Pybus was an investor in the Harley Street development, or just that he knew of it at an early date.

In the same year as he was issued the lease of 81 Harley Street, 1773, Pybus seems to have been considering a return to India, writing to the Company's Court of Directors for permission to return on the grounds that his health had recovered. Perhaps he did not expect to be sent back, as he also set about establishing himself in business in London, founding the banking partnership of Pybus, Hyde, Dorset and Cockell in New Bond Street. 61

Pybus remained in Harley Street until $1784 .{ }^{62} \mathrm{He}$ died at his new house in New Bond Street in 1789, leaving a lengthy and unusually detailed will. ${ }^{63}$ Many of the individual items listed had no doubt once graced 81 Harley Street, and thus provide an insight into the richness of the interiors of these outwardly plain houses. There were several portraits, mostly of himself and his wife described as being 'by Stuart' (perhaps Gilbert Stuart, who was working in London from 1777 to 1787). These are most likely still in private hands, assuming that they have survived, but one painting can be identified as the conversation piece painted shortly after their return from India by the fashionable portraitist Nathaniel Dance, now in the National Gallery of Victoria, Melbourne, Australia (Figure 9). ${ }^{64}$ The family are grouped in an idyllic 
landscape, the father resting his hand on the shoulder of his youngest child - his second son Charles Small Pybus who is standing on his mother, Martha's, lap. Seated on the ground is the eldest son, also John, and to the side stand two daughters: Martha, on the left, and Anne. It is interesting that this family portrait contains no hint of their time in India, unlike many commissioned by returning East India Company employees, who had themselves painted wearing Indian dress, with native attendants or accoutrements such as hookah pipes. ${ }^{65}$

In addition to paintings, various items of furniture were mentioned, mostly mahogany pieces, such as a large bookcase and bedsteads upholstered in chintz. The chintz was presumably from India, as also an India Blackwood inlaid chest of drawers mounted with silver and a clothes press or wardrobe 'thereunto belonging' which had been 'lately altered by Simpson, upholsterer'. Explicitly brought back from India was an India inlaid mahogany chest of drawers mounted with silver, which also had a matching wardrobe or clothes press. It is noticeable that these exotic pieces of furniture would have been in the bedrooms or dressing rooms, the private side of the house. The one item mentioned which would have been on public display was not from India, it was a Shudi and Broadwood harpsichord.

There were also many smaller decorative items. To his wife Pybus left a pair of gold 'fillagree' trunks or boxes which he had bought from George Smith, a merchant in Fort St George shortly before he left India, and 'a large fillagree rosewater bottle and tree lately gilt by Heming', presumably the goldsmith Thomas Heming, whose shop was on New Bond Street. 66 There were also silver tea canisters and 'a dressing box and frame of a looking glass for a toilet.' The looking glass may have been of the type made in Vizagapatam (now Vishakhapatnam), or Mursdabad specifically for the western market. ${ }^{67}$ Other silverware more particularly described were a 'gilt monteith of silver' which he claimed had been given to his father by the Earl of Burlington and a silver cup and cover, another gift to his father this time given by the Marchioness of Rockingham. A more recent acquisition was a large silver tea table, weighing 230 ounces, bought from Timothy Davies, silversmith, of Bond Street.

As so many of his contemporary returnees from India, Pybus invested in property and at the time of his death owned the leases of thirteen houses in Bunhill Row, Moorfields, and a country estate at Cheam, Surrey, which he had purchased from Edward Sanxay in 1787.68 The house no longer survives, but the Pybus family memorials can be found in the Lumley chapel, in the grounds of St Dunstan's Church in Cheam.

In 1775 Pybus had stood for election as a director of the East India Company, though he was not successful. He had plenty of contacts within the Company, not least his brother-in-law Thomas Bates Rous, who served as a director from 1773 to 1779 , and who moved into the house opposite the Pybus's in Harley Street (now No. 76) in 1776. ${ }^{69}$ Bates Rous had in fact followed Pybus here from Berners Street, 
where he had lived next-door but one to William Chambers, and a few doors up from his brother-in-law, similarly taking that house from new in 1769.

There were numerous other serving directors who took houses in and around Harley Street, including Stephen Lushington and John Smith Burges at 69 and 102 Harley Street respectively in the 1780s and 1790s; William Fullarton Elphinstone at No. 92 in the early nineteenth century, and William Wigram from the late 1820 s to the 1850 s. ${ }^{70}$ Of the thirty-four men who served on the Court of Directors between 1838 and 1842, seventeen were living in Marylebone at the time they were a director, precisely half. The next most popular London address was Mayfair, with only seven directors. ${ }^{71}$ A brief analysis of the occupants of all 146 houses in Harley Street in 1840 found 27 with some connection to the East India Company, 20 politicians, 17 in the legal profession, 13 with slave-owning connections in the West Indies, 9 in the medical professions and 8 bankers. ${ }^{72}$ No information could be gleaned for the occupants of 43 of the houses. Although there is some degree of overlap in these categories, those with Indian connections form the largest group. Whilst similar analysis of other areas in London must be left to others to conduct, it is clear that the London residences of East India Company directors from around 1820 to 1840 have a noticeable Marylebone bias. During that period Marylebone always housed more directors than any other district, by some considerable margin over Mayfair - the next most popular and fashionable address.

\section{Conclusion}

During the second half of the eighteenth century and into the early decades of the nineteenth many people living in and around Harley Street had connections to the East India Company. They included many serving and former directors. The newer houses north of New Cavendish Street, which were somewhat larger, proved particularly popular. Apart from access to the New Road, at the north end of Harley Street, which eased travel into the City, and to East India House, the neighbourhood was also convenient for parliament. Many MPs and a smattering of Lords and Bishops resided here, perhaps a further lure to someone with an eye on a parliamentary seat and political advancement.

The colonization of Marylebone by those with East India Company connections was largely due to the availability of good houses coupled with either family connections or ties of friendship with those already resident there. It was Orme's early years in Cavendish Square together with the proximity of his friends which would have dictated a wish to return to settle. His wish was easily fulfilled by the number of new houses going up in the area around Cavendish Square which created an oversupply and therefore competitive rents. This abundance of new housing in a fashionable location became available at the same time as the first nabobs appeared on the London scene, and continued 
through the peak years of the 1770 s and 80 s by which time the character of the nabob had become firmly established in Britain. By the final years of the eighteenth century this part of Marylebone provided an address with cachet. For East India Company men there was also a comforting number of residents with the shared experience of having lived in South Asia. The outward anonymity and respectability of these terraced houses screened their occupants from the officious gaze of the critics of nabobery, masking interiors where the trappings of Indian wealth could be displayed in the public rooms, or hidden away in private apartments.

In the popular culture of the period, the area came to be recognized as an enclave of Nabobs. ${ }^{73}$ It was perhaps the presence of General Smith, the Nabob of Nabobs, which cemented the area's reputation, or ensured its notoriety. But quantitative analysis suggests it was not just nabobian visibility and notoriety which gave rise to this popular view. The perception had some basis in facts.

By the early nineteenth century the small area in Marylebone between Portland Place and Wimpole Street had become well known as a centre of the Anglo-Indian community in London, and Harley Street itself was as synonymous with Nabobs as it was later to be with the medical profession. As late as 1841, Harley Street was still being described as 'the headquarters of oriental nabobs'. Here 'the claret is poor stuff, but Harley Street Madeira has passed into a proverb, and nowhere are curries and mulligatawny given in equal style'. ${ }^{74}$

\section{Notes}

1 - East India Company at Home, 1757-1857 (2011-14), see

blogs.ucl.ac.uk/eicah/home.

2 - Legacies of British Slave-ownership, 2009-15, see www.ucl.ac.uk/1bs <accessed $14 / 03 / 2016>$

3 - The material presented here derives from research carried out for the Survey of London and many of its findings are destined for publication in brief form in volumes 51 and 52 of the Survey of London series which will cover South-eastern St Marylebone. A version of this paper was presented at the East India Company at Home end-of-project conference, Objects, Families, Homes: British Material Cultures in Global Context, at University College London in July 2014.

4 - Consequent misapprehensions were evident at the East India Company at Home conference (see note 3). See also, for example, R. Stewart, The Town House in Georgian London (London: Yale University Press, 2009). J. M. Holzman, The nabobs in England: a study of the returned Anglo-Indian, 1760-1785 (New York, 1926), and T. W. Nechtman, Empire and Identity in Eighteenth-Century Britain (Cambridge: Cambridge University Press, 2013), studied the material culture of those returning from South Asia but concentrated on country estates rather than London property holdings.

5 - For a study of settlers in London from America and the West Indies see J. Flavell, When London was the Capital of America (London: Yale University Press, 2010). 6 - P. J. Marshall, East Indian Fortunes: The British in Bengal in the Eighteenth Century (Oxford: Clarendon Press, 1976), 215: see also H.V. Bowen, The Business of Empire: The East India Company and Imperial Britain 1756-1833 (Cambridge: Cambridge University Press, 2006). 7 - E. McKellar, Landscapes of London (London: Yale University Press, 2013), passim, see, for example, 209-12. 
8 - See, for example, A. Webster, The Twilight of the East India Company. The evolution of Anglo-Asian Commerce and politics, 1790-1860 (Woodbridge: Boydell Press, 2009).

9 - London Metropolitan Archives (hereafter LMA), MDR/1729/3/219; City of Westminster Archives Centre, St Marylebone ratebooks (hereafter RB); P. Watson and P. Gauci, 'Shepheard, Francis (1676-1739), of London, and Exning, Suff.', in The History of Parliament: the House of Commons 1690-1715 (Cambridge: Cambridge University Press, 2002), see www.historyofparliamentonline.org/volume/1690$1715 /$ member/shepheard-francis-1676-1739 <accessed 14/03/2016>.

10 - Watson and Gauci, 'Shepheard, Samuel I (c.1648-1719), of St Magnus the Martyr, and Bishopsgate Street, London', in History of Parliament, see www.historyofparliamentonline.org/volume/1690-1715/member/shepheardsamuel-i-1648-1719; P. Carter, 'Shepheard, Samuel (c.1648-1719)', Oxford Dictionary of National Biography (Oxford: Oxford University Press, 2004) (hereafter ODNB), see www.oxforddnb.com/view/article/67062 <accessed 14/03/2016>.

11 - The National Archives (hereafter TNA), PROB11/567/81.

12 - C. Henry \& M. I. Collins Baker, The Life and Circumstances of James Brydges, First Duke of Chandos, Patron of the Liberal Arts (Oxford: Clarendon Press, 1949); Susan Jenkins, Portrait of a Patron: The Patronage and Collecting of James Brydges, 1st Duke of Chandos (1674-1744) (Aldershot: Ashgate, 2007).

13 - LMA, MDR 1724/6/158-61; Jenkins, Chandos, 101-4; Survey of London, 29: St James, Westminster, South of Piccadilly (London, 1960), 120-2.

14 - LMA, MDR 1731/2/75-8.

15 - Both quotes are as in Collins Baker, Chandos, 279; Jenkins, Chandos, 104. 16 - British Library (hereafter BL), IOR/G/37/1, letter from John Johnson, 19 February 1715/16; IOR/D/19, f. 35, Robert Adams's memorial of 1729; IOR/B/62, 355; Leicestershire Record Office (hereafter LRO), DE3214/10388; A. Hamilton, $A$ New Account of the East Indies, 1 (London, 1744), 298-301,315-18; M. O. Koshy, The Dutch Power in Kerala, 1729-1758 (New Delhi: Mittal Publications, 1989), 38-9; R. J. Barendse, Arabian Seas 1700-1763: vol. 1, The Western Indian Ocean in the eighteenth century (Leiden: Brill, 2009), 538-9.

17 - Hamilton, East Indies, 299; John Keay, The Honourable Company: A History of the English East India Company (London: Harper Collins, 1991), 250-4.

18 - Hamilton, East Indies, 317-18.

$19-\mathrm{BL}, \mathrm{IOR} / \mathrm{B} / 60,309$.

20 - BL, IOR/B/61, passim; IOR/D/19, 35.

$21-\mathrm{BL}, \mathrm{IOR} / \mathrm{B} / 61,20$ and 36.

$22-\mathrm{BL}, \mathrm{IOR} / \mathrm{B} / 61,215$.

23 - BL, IOR/B/60, 420; IOR/E/1/21/45, letter of 5 February 1729/30 from Robert Adams.

24 - LRO, DE3214/10388.

25 - College of Arms, Grants 8, 148r.

26 - Royal Commission on Historical Manuscripts, The manuscripts of His Grace the Duke of Portland, [formerly] preserved at Welbeck Abbey, vol. 6 (London, 1901), 56; BL, IOR/B/62, passim: LRO, DE3214/9750/1.

27 - J. Ralph, A Critical Review of the Publick Buildings, Statues and Ornaments in and around London and Westminster (London, 1734), 106.

28 - Gentleman's Magazine, viii/1, April 1738, 221; Derby Mercury, 13 April 1738.

29 - S. Tammita-Delgoda, 'Orme, Robert (1728-1801)', ODNB, see

www.oxforddnb.com/view/article/20833 <accessed 14/03/2016>.

30 - RB; LRO, DE3214/3606; DE3214/10172; S. Harratt, 'Noel, Sir Gerard Noel, 2nd bt. (1759-1838), of Exton Park, Rutland', The History of Parliament: the House of Commons 1820-1832 (Cambridge: Cambridge University Press, 2009), see www.historyofparliamentonline.org/volume/1820-1832/member/noel-sir-gerard1759-1838 <accessed 14/03/2016>.

31 - City of Westminster Archives Centre, Ashbridge Collection, 160/CAV, pencil sketch by Jean-Claude Nattes, c.1805; Building News, 3 August 1894, 141. 32 - Howard de Walden Estate Archives, HDW 6/1, Survey 'touching the nature and 
condition' of the Marylebone estate, 1737; RB; J. Rocque, Survey of London, Westminster, and Southwark and the Country near Ten Miles Round 1746.

33 - RB. No. 11 Harley Street became No. 16 in the 1820s and was latterly No. 34. A block of flats now stands on the site.

34 - S. Tammita-Delgoda, "Nabob, Historian and Orientalist" The Life and Writings of Robert Orme (1728-1801)' (PhD thesis, Kings College London, 1991), 24, 28-68, 153

35 - Ibid., 69.

36 - R. Winfield, British Warships in the Age of Sail 1714-1792 (Barnsley: Seaforth, 2007), 33.

37 - RB; TNA, PROB11/920/192.

38 - Gazetteer \& New Daily Advertiser, 8 Dec 1766.

$39-\mathrm{RB}$.

40 - RB; Sir Lewis Namier, 'Olmius, Drigue Billers, $2^{\text {nd }}$ Baron Waltham [I] (1746-87), of New Hall, Boreham, Essex', The History of Parliament: the House of Commons 1754-1790 (London: H.M.S.O, 1964), see www.historyofparliamentonline.org/volume/1754-1790/member/olmius-driguebillers-1746-87 <accessed 14/03/2016>; S. Reid, 'Morris, Staats Long (1728-1800)', ODNB, see www.oxforddnb.com/view/article/68360; Tammita-Delgoda, "Nabob, Historian and Orientalist"', 69.

41 - Howard de Walden Estate Archives, property files.

42 - R. Orme, Historical Fragments of the Mogul Empire (London, 1805), xlix;

Tammita-Delgoda, "Nabob, Historian and Orientalist"', 146-8.

43 - Tammita-Delgoda, "Nabob, Historian and Orientalist", 79; RB; Gazetteer \& New Daily Advertiser, 28 April 1770.

44 - RB; LMA, MDR 1754/4/242-3: www.thepeerage.com/p14044.htm < accessed $14 / 03 / 2016>$.

45 - Historic England, London Region photographs, copies also in LMA, SC/PHL/01/311/57/3669 and SC/PHL/01/311/59/2534.

46 - Museum of English Rural Life, BER 36/5/200; RB; D. L. Prior, 'Holwell, John Zephaniah (1711-1798)', ODNB, see www.oxforddnb.com/view/article/13622 <accessed 14/03/2016>.

47 - S. Foote, 'The Nabob: A comedy...' (London, 1778); Town and Country Magazine, vol. 8, 1776, 345-7; Survey of London, 30: St James, Westminster, South of Piccadilly (London, 1960), 442-3.

48 - quoted in T. W. Nechtman, Nabobs Empire and Identity in Eighteenth-century Britain (Cambridge: Cambridge University Press, 2010), 165-6.

49 - G. J. Bryant, 'Smith, Richard (bap. 1734, d. 1803)', ODNB, see www.oxforddnb.com/view/article/63539; J. Price, A Vindication of Gen. Richard Smith..., $2^{\text {nd }}$ edn (London, 1783).

50 - Smith, ODNB.

51 - Public Advertiser, 1 Nov 1785.

52 - The Times, 4 April 1788.

53 - The World, 29 Sept 1788.

54 - Bath Chronicle, 20 Nov 1788.

55 - The World, 29 April 1791; Morning Post and Daily Advertiser, 9 May 1791.

56 - Gazetteer \& New Daily Advertiser, 21 Nov 1765.

$57-\mathrm{RB}$.

58 - Howard de Walden Estate Archives, HDW 3/3.

59 - Account of Mr Pybus's Mission to the King of Kandy, In 1762 (Colombo: W. Skeen, 1862).

$60-\mathrm{RB}$; the ratebook for 1768 is missing, and the house does not appear in the ratebook for 1767 .

$61-$ BL, IOR/E/1/57, 492-3v; BL, Mss EurF110; J. M. Holzman, Nabobs in England (New York, 1926), 76, 158; F. G. Hilton Price, Handbook of London Bankers (London, 1876), 25-6.

$62-\mathrm{RB}$.

63 - TNA, PROB11/1184/72.

64 - E. Lauze, 'A Nabob's return: the Pybus conversation piece by Nathaniel Dance', 
in National Gallery of Victoria Art Bulletin 43, 2 June 2014, see

publications.ngv.vic.gov.au/artjournal/a-nabobs-return-the-pybus-conversationpiece-by-nathaniel-dance/\#.VD-pWfnF To <accessed 14/03/2016>.

$65-\mathrm{M}$. Archer, India and British Portraiture, 1770-1825 (London: Philip Wilson, 1979), 487-519.

66 - E. Packer, 'Heming, Thomas', Grove Art Online, see http://www.oxfordartonline.com.libproxy.ucl.ac.uk/subscriber/article/grove/art/T 037481?q=Heming\%2C+Thomas\&search=quick\&pos=1\&_start $=1<$ accessed $14 / 03 / 2016>$. 67 - J. P. Losty et al., 'Indian subcontinent', Grove Art Online, see http://www.oxfordartonline.com.libproxy.ucl.ac.uk/subscriber/article/grove/art/T 040113?q=Indian+subcontinent\&search=quick\&pos=1\&_start=1 pg54 <accessed 14/03/2016>; collections.vam.ac.uk/item/090270/toilet-glass-unknown/<accessed $14 / 03 / 2016>$.

68 - Gazetteer \& New Daily Advertiser, 5 Dec 1787.

$69-\mathrm{RB}$.

70 - J. G. Parker, 'The Directors of the East India Company 1754-1790', PhD thesis, University of Edinburgh, 1977, 114-17, 165-8, 229-30; Boyle's Court Guides; RB. 71 - Information derived from lists of directors published in the Asiatic Journal. 72 - RB; Post Office Directories; Census; numerous sources were consulted to identify occupations and affiliations of the residents, too numerous to cite here, but most began with a simple google search on the name.

73 - Blackwood's Edinburgh Magazine, July-December 1841, 71; C. G. F. Gore, The Sketch Book of Fashion (London, 1833), 170-1: W. M. Thackeray, The Newcomes, vol. 1 (London, 1854), 81.

74 - Blackwood's Edinburgh Magazine, July-December 1841, p. 71.

\section{Captions and Figure Credits}

Figure 1 - Francis Shepheard's painted staircase at 20 Cavendish Square. Photographed in 2014 by Chris Redgrave (c) Historic England

Figure 2 - Robert Adams's house at 9 Cavendish Square. Photographed in 1891, Bedford Lemere, (C) Historic England

Figure 3 - Robert Adams's coat of arms, granted 1732. College of Arms Grants 8 148r, (C) College of Arms

Figure 4 - Extract from Horwood's Map of London, surveyed in 1792, showing the houses (with original numbering) of: Robert Orme (11 Harley Street, later No.34); General Richard Smith (5 Harley Street, later No.22); Robert Adams (8 Cavendish Square, later No.9); and Francis Shepheard (16 Cavendish Square, later No.20). (C) London Metropolitan Archives, Corporation of London

Figure 5 - A view of Harley Street taken c.1930 showing Robert Orme's former house on the far right. From The Metropolitan Borough of St. Marylebone Official Guide, n.d.p.111

Figure 6 - Nos 22-28 Harley Street. General Richard Smith's house at 22 Harley Street to the right. Photographed in 1957, (C) London Metropolitan Archives, Corporation of London 
Figure 7 - Entrance hall in 22 Harley Street. Photographed in 1959, (c) London Metropolitan Archives, Corporation of London

Figure 8 - John Pybus's house at 81 Harley Street. Photographed in 2014 by Chris Redgrave (C) Historic England

Figure 9 - The Pybus family, conversation piece painted by Nathaniel Dance c.1769. (C) The National Gallery of Victoria, Melbourne, Australia 